\title{
GEOLOGIC STRUCTURE AND SEISMICITY OF ESTONIA
}

\author{
Heldur SILDVEE and Rein VAHER
}

Eesti Teaduste Akadeemia Geoloogia Instituut (Institute of Geology, Estonian Academy of Sciences), Estonia pst. 7, EE-0100 Tallinn, Eesti (Estonia)

Presented by V. Puura

Received 15 April 1994, accepted 27 September 1994

Abstract. Two highly conducting regions have been identified in the Estonian mantle at mean depths of 75 and $160 \mathrm{~km}$. The crust is $35-50 \mathrm{~km}$ thick. It is broken into blocks by deep-seated faults. Structural trends in the strongly folded Precambrian basement vary within large limits. The basement is covered with a maximum of $1 \mathrm{~km}$ of slightly disturbed sedimentary rocks.

Observations of earthquake occurrences cover the time from 1602 to the present. The macroseismically derived magnitudes range from 1 to 5 . The earthquakes are apparently largely concentrated in the central part of the upper crust at depths of 5-10 km. The macroseismic epicentre distribution does not reveal any distinct seismicity pattern. A possible connection between the observed earthquakes and the known structure zones is discussed.

Key words: geologic structure, seismicity, Estonia.

\section{INTRODUCTION}

The historical records, though incomplete and fragmentary, provide a certain quantitative picture of Estonian seismicity. Compared with a previous review (Nikonov \& Sildvee, 1992) that covers the time from 1670 to 1976 , this paper is more comprehensive and contains additional macroseismic data up till 1989. Besides, the instrumental epicentre distributions of events with a magnitude below three observed in 1988-91 by the Institute of Seismology, University of Helsinki, are shown. Much more attention is also given to the structural features of the region.

\section{GEOLOGIC STRUCTURE}

Magnetotelluric measurements were made in Estonia in 1970-72 (Андра et al., 1974). Fig. 1 shows the survey area. The interpretation of the magnetotelluric data gave the mean value for the depth of the highly conducting layer in the mantle as $75 \mathrm{~km}$. The standard deviation of the mean, based on eight figures for the depth, is $2.3 \mathrm{~km}$. For three stations it was possible to estimate the depth $(140-180 \mathrm{~km})$ of another highly conducting layer. 


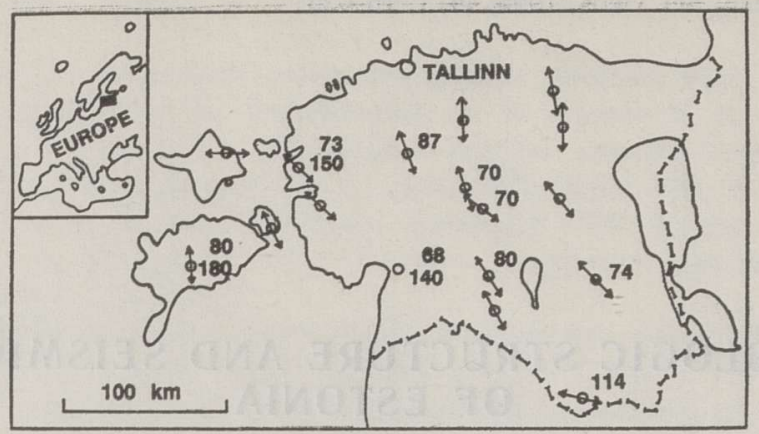

Fig. 1. Location of the magnetotelluric sites (Андра et al., 1974) with the depth of the highly conducting regions in the mantle in kilometres. Arrows represent the average polarization angles for the telluric field.

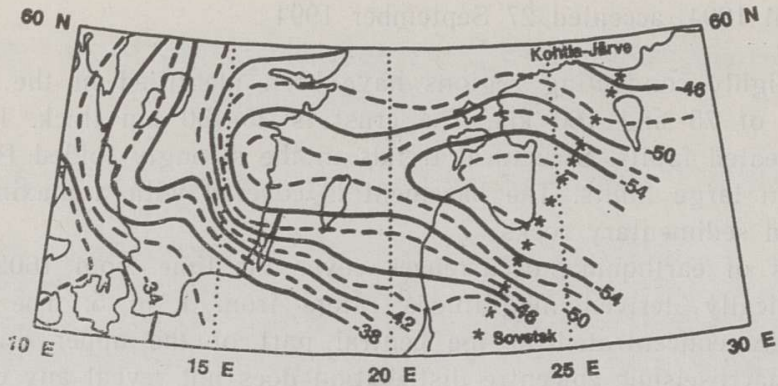

Fig. 2. Map with Moho depth contours (excerpted from Luosto, 1991). Depths are indicated in kilometres as negative from the Earth's surface. Asterisks represent the shotpoints on the Sovetsk-Kohtla-Järve deep seismic sounding profile.

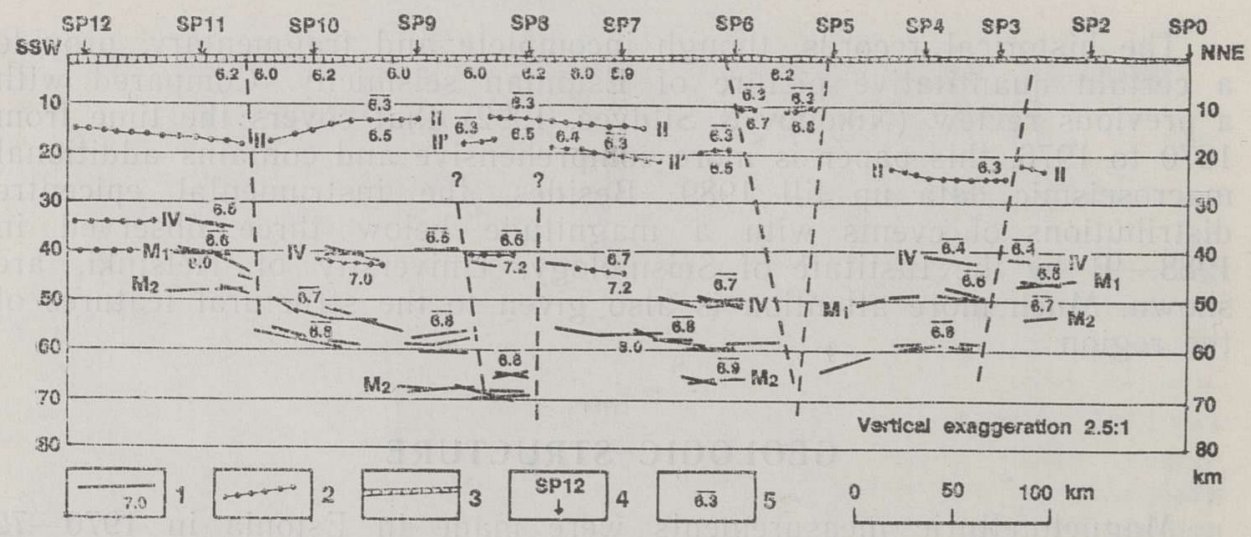

Fig. 3. Interpretive crustal section along the Sovetsk-Kohtla-Järve profile (simplified from Анкудинов et al., 1994).

1 refraction discontinuities, velocity of $\mathrm{P}$ waves in $\mathrm{km} / \mathrm{s}$ immediately below the discontinuity; 2 reflection discontinuities; 3 sedimentary cover; 4 shotpoint; 5 average velocity of upper media. II Conrad discontinuity, M Mohorovičič discontinuity. 
Luosto (1991) shows an almost east-west-oriented crustal depression in the Baltic Proper (Fig. 2). It was based on the FENNOLORA seismic refraction profile, on which the field work was done in 1979, and the Sovetsk-Kohtla-Järve profile, studied in 1983-86. The location of the latter is shown in Fig. 2.

According to the interpretation of Sovetsk-Kohtla-Järve profile by Sadov and Penzina (Шаров et al., 1989; Анкудинов et al., 1994), the crust is about $60 \mathrm{~km}$ thick in the middle of the depression (Fig. 3). Smaller Moho depth values of 40 to $46 \mathrm{~km}$ were observed at the ends of the profile. In the Estonian part of the profile the crust is $46-51 \mathrm{~km}$ thick. Bulin (Булин, 1978) suggested a preliminary depth of about $42-47 \mathrm{~km}$ for the Mohorovičič discontinuity in northwestern Estonia (Fig. 4, left). A reinterpretation (Булин et al., 1980) gave smaller depth values of 36 to $44 \mathrm{~km}$ for this area (Fig. 4, right). Deep-seated faults break the crust into blocks (Fig. 3).

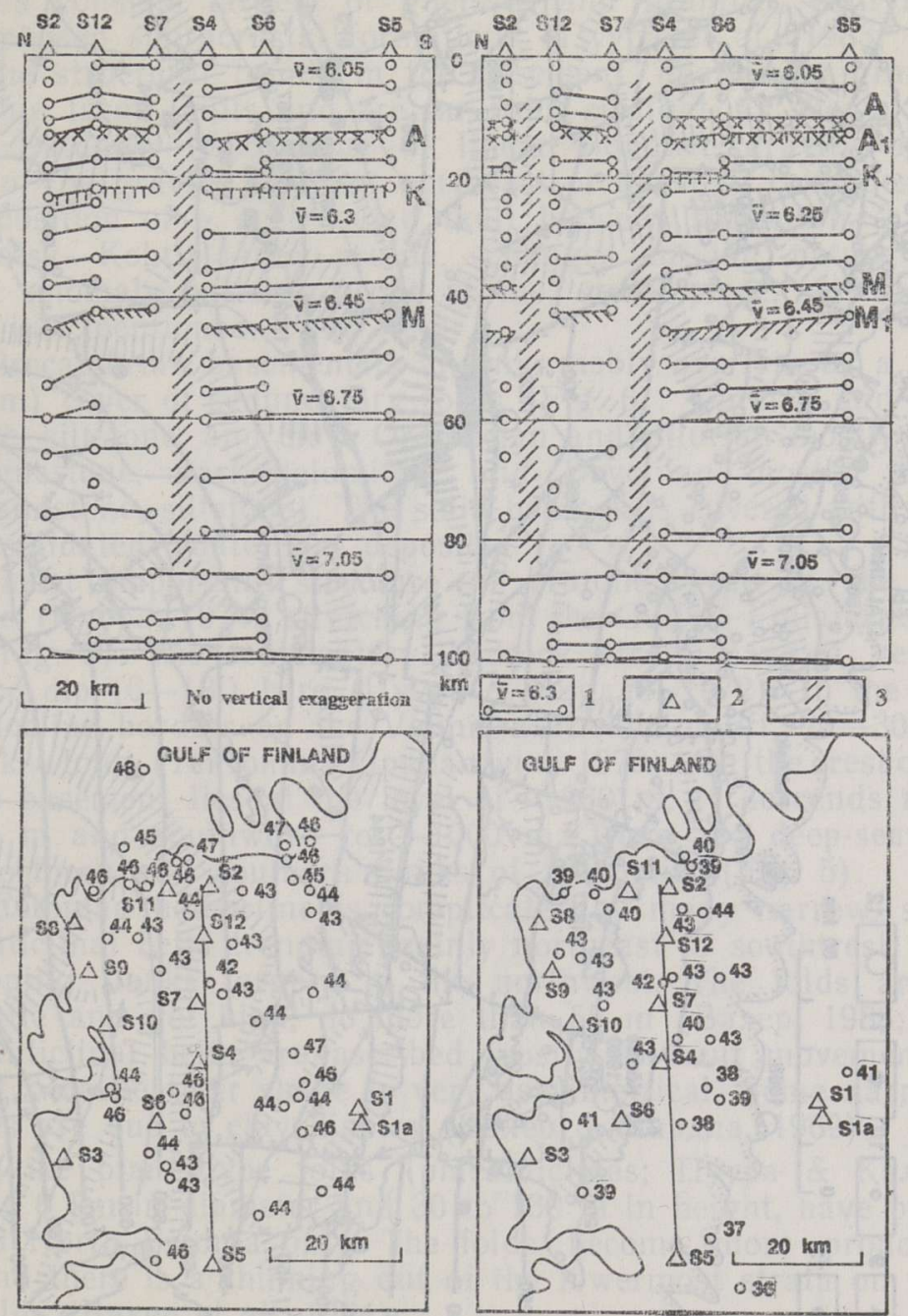

Fig. 4. Maps with Moho depths in kilometres and crustal sections, northwestern Estonia (left: Булин, 1978; right: Булин et al., 1980).

1 seismic station; 2 discontinuity with average velocity of the upper medium; 3 assumed deep-seated fault. K Conrad discontinuity, $\mathbf{M}$ Mohorovičič discontinuity. 


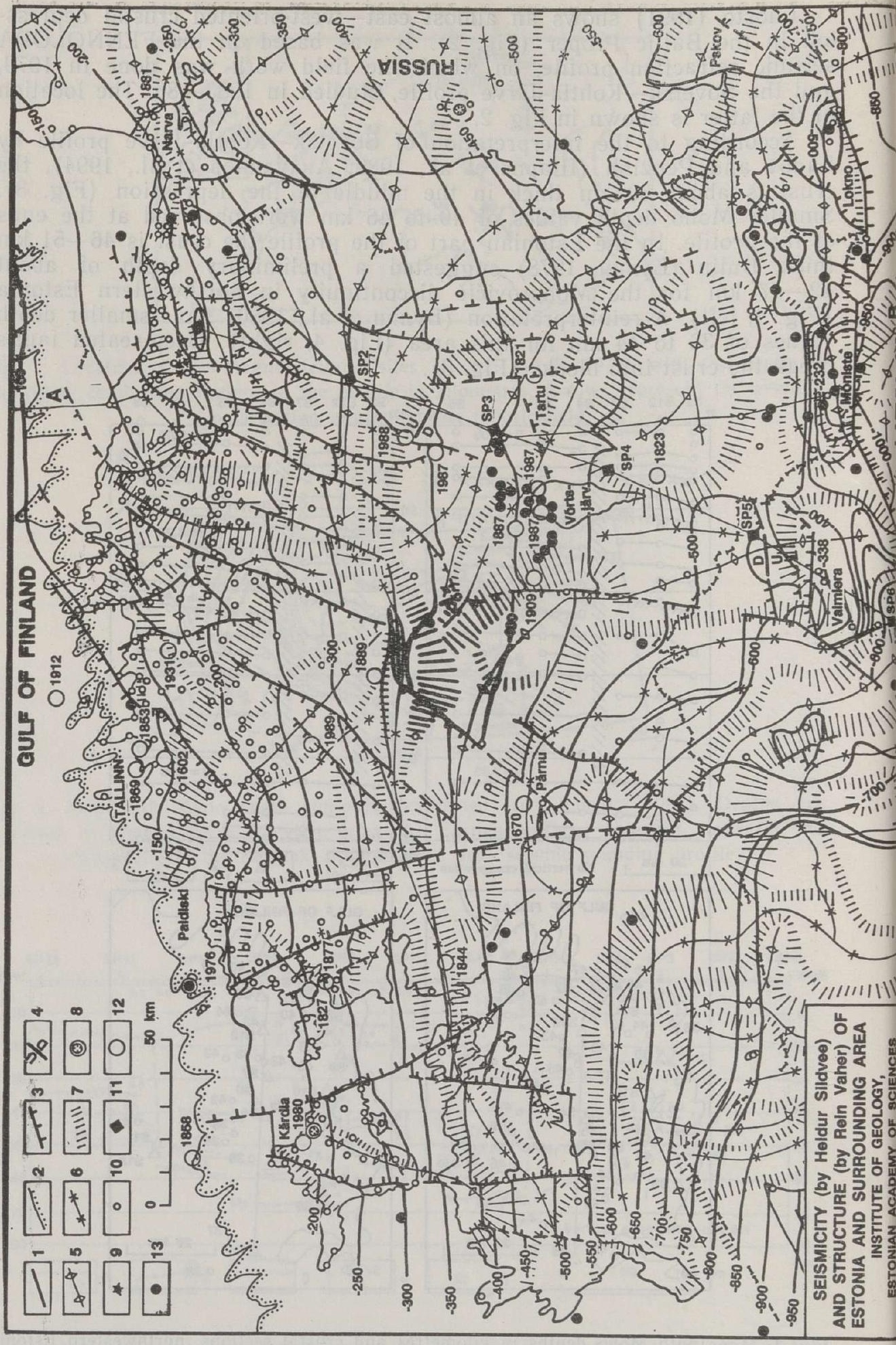


Fig. 5. Seismicity and structure of Estonia and the surrounding area. Data from: Geological Survey of Estonia; Institute of Geology, Estonian Academy of Sciences; Institute of Seismology, University of Helsinki; All-Russian Geological Research Institute (VSEGEI); Northwest State Geological Enterprise (SEVZAPGEOLOGIA), Russia; Latvijas Geologija. 1 contour on top of the Precambrian basement; 2 updip limit of the sedimentary bedrock; 3 flexure above a basement fault; 4 deep-seated fault: U upthrown side, D - downthrown side; $5-7$ trend of Bouguer anomaly: high (5), low (6), gradient (7); 8 crater; 9 dome; 10 borehole finished in the basement; 11 shotpoint; 12, 13 earthquakes: macroseismic (12), instrumental (13).

The strongly disturbed and metamonphosed Precambrian basement of Estonia consists largely of gneisses and granites, with some less metamorphosed supracrustal formations (Пyypa et al., 1983; Koistinen, 1994). The structural trends in the basement, imaged by gravity data, vary within large limits and are far from straight, as shown in Fig. 5. Note the Paldiski-Pskov zone of linear Bouguer gravity highs. The position of the gravity gradient northeast of the high coincides with the surface position of a deep-seated fault between shotpoints 2 and 3 of the Sovetsk-Kohtla-Järve profile. Changes in the nature of aeromagnetic anomaly patterns occur at the same place, at the gravity gradient just mentioned.

The Precambrian basement is unconformably overlain by a thin (less than $1 \mathrm{~km}$ ) cover of sedimentary rocks (Fig. 6): Vendian and Cambrian sandstone, siltstone, and clay; Ordovician and Silurian mostly carbonate rocks (limestone, marl, dolomite); and Devonian mostly terrigenous rocks (sandstone, siltstone). The solid bedrock is covered with a blanket of unconsolidated Quaternary deposits.

The most important structure of cratonic type is the Estonian homocline (Пуура, 1974) stretching from the Gulf of Finland to northern Latvia (Fig. 5). The sedimentary bedrock strata have a very gentle southward dip (6-18') here (Пуура \& Мардла, 1972). In the southeast this homocline borders on the Valmiera-Lokno uplift, 20-30 km wide and $200 \mathrm{~km}$ long (Тектоника Прибалтики, 1979). On the crest of the anticline the basement lies at the level of $-230 \mathrm{~m}$. It descends northward to $-500 \mathrm{~m}$ and southward to $-1000 \mathrm{~m}$. There are deep-seated faults in the northern and southern flanks of the uplift (Fig. 5).

The Estonian homocline is complicated by many narrow, some 1 to $4 \mathrm{~km}$, anticlinal belts trending mainly northeast to southwest, and their steep-dipping flanks largely to the northwest. The folds are usually very gentle and not high, no more than $50 \mathrm{~m}$ (Вахер, 1983; Туулинг, 1990). Anticlinal belts are ascribed mostly to fault movements in the basement because their shape is very asymmetrical. Some narrow linear structures are due to clay diapirs (Вахер \& Мардла, 1969).

Dome-like plains-type folds (placanticlines; Пуура \& Кала, 1978), some 1 to $6 \mathrm{~km}$ in diameter and 30 to $130 \mathrm{~m}$ in height, have been found so far in North Estonia only. The folds become more pronounced in depth, and there is a thinning out of the lowermost strata on the flanks of the folds (Baxep et al., 1964).

The Kärdla buried impact crater of Hiiumaa Island developed in the Middle Ordovician. Its diameter is $4 \mathrm{~km}$. The crater is $540 \mathrm{~m}$ deep and has an about $100 \mathrm{~m}$ high central peak. The highest parts of the rim rise up to $100 \mathrm{~m}$ above the original target rock level and up to $240 \mathrm{~m}$ above the basement level of the surrounding area (Puura \& Suuroja, 1992). 


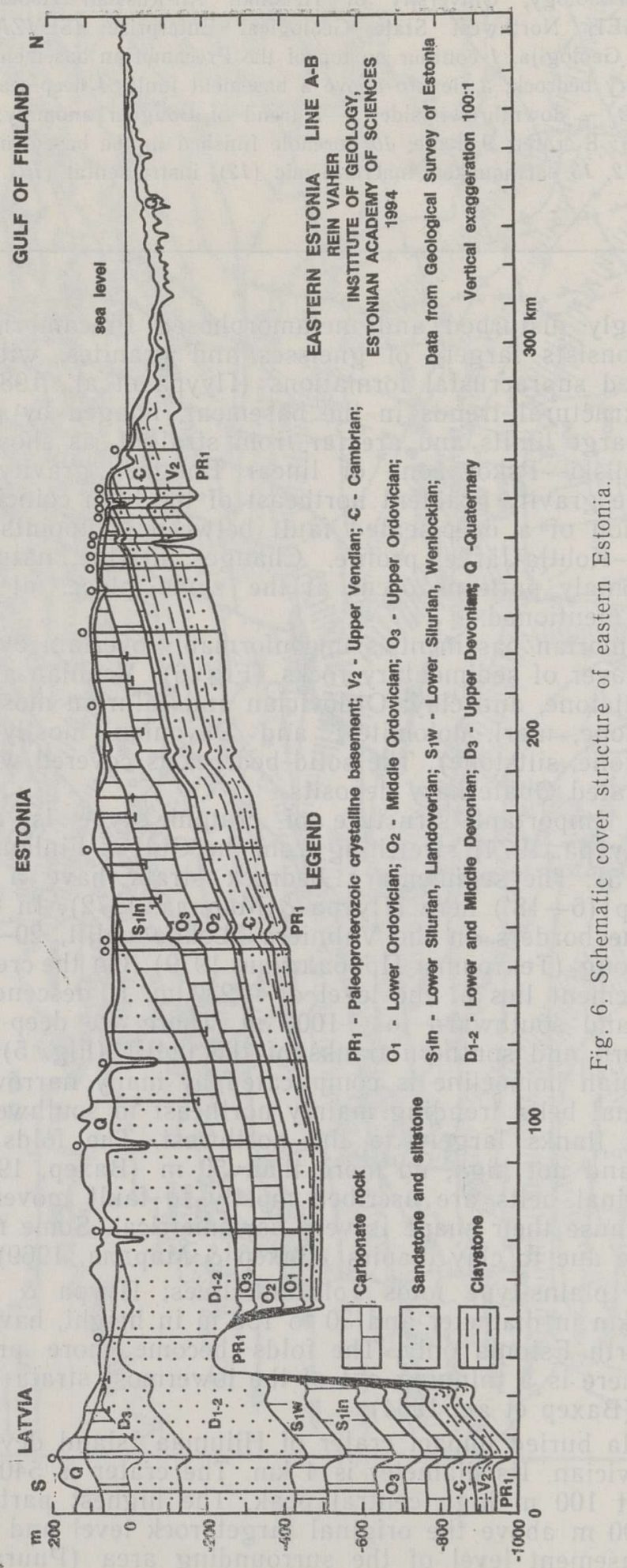




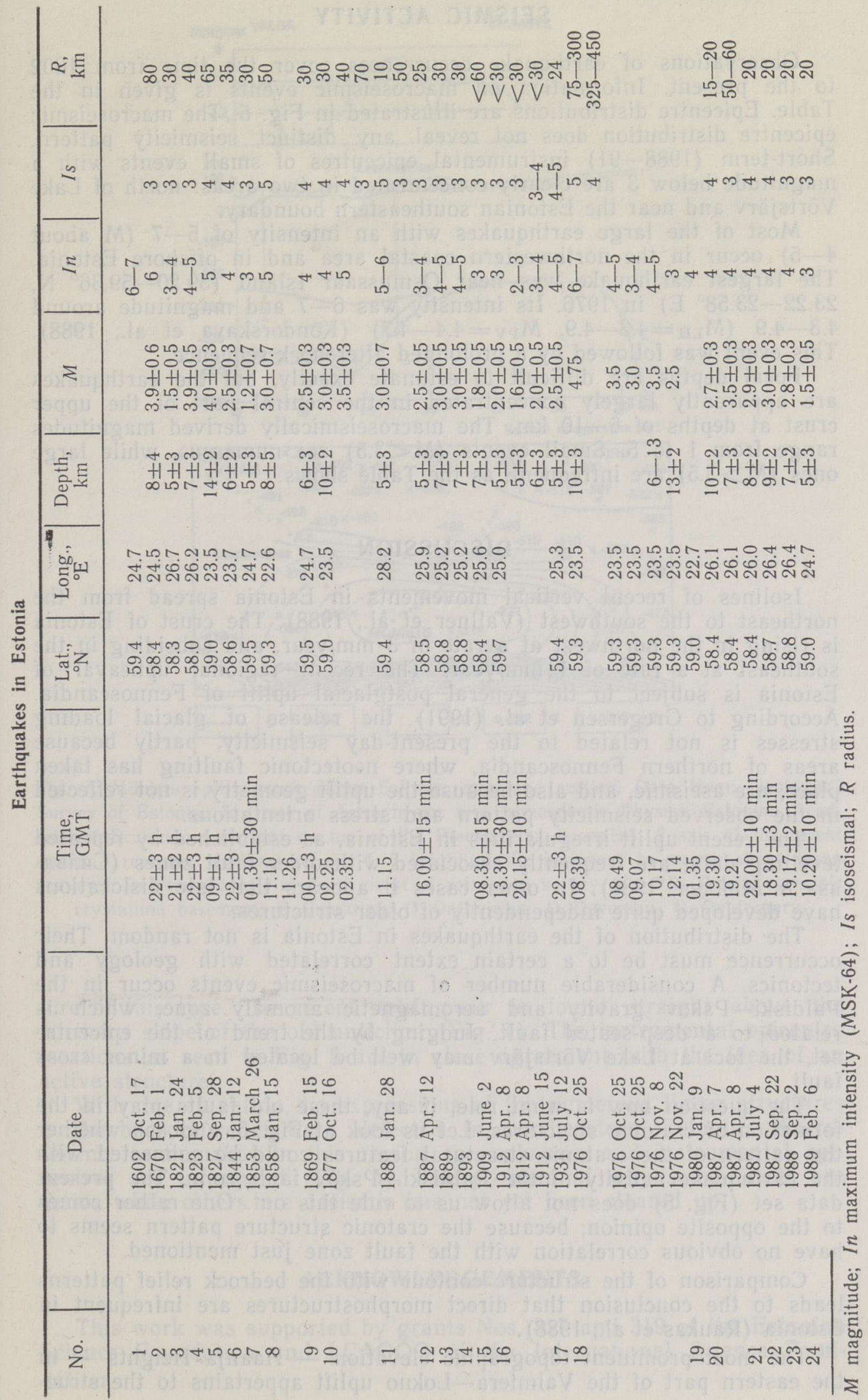




\section{SEISMIC ACTIVITY}

Observations of earthquake occurrences cover the time from 1602 to the present. Information on macroseismic events is given in the Table. Epicentre distributions are illustrated in Fig. 5. The macroseismic epicentre distribution does not reveal any distinct seismicity pattern. Short-term (1988-91) instrumental epicentres of small events with a magnitude below 3 are clearly concentrated in two areas: north of Lake Võrtsjärv and near the Estonian southeastern boundary.

Most of the large earthquakes with an intensity of $5-7$ ( $M$ about $4-5)$ occur in the northwestern coastal area and in offshore Estonia. The largest earthquake was near Osmussaar Island $\left(59.20-59.36^{\circ} \mathrm{N}\right.$, $\left.23.22-23.58^{\circ} \mathrm{E}\right)$ in 1976 . Its intensity was $6-7$ and magnitude around 4.3-4.9 $\left(\mathrm{M}_{\mathrm{LH}}=4.3-4.9, \quad \mathrm{M}_{\mathrm{PV}}=4.4-4.7\right) \quad$ (Kondorskaya et al., 1988). This event was followed by a prolonged aftershock sequence.

Focal depths are difficult to estimate exactly, but the earthquakes are apparently largely concentrated in the central part of the upper crust at depths of $5-10 \mathrm{~km}$. The macroseismically derived magnitudes range from 1 to 5 . Small events $(M<3.5)$ are numerous, while large ones $(M>3.5)$ are infrequent, as the Table shows.

\section{DISCUSSION}

Isolines of recent vertical movements in Estonia spread from the northeast to the southwest (Vallner et al., 1988). The crust of Estonia is rising in the northwest at a rate of $3 \mathrm{~mm} / \mathrm{year}$, and subsiding in the southeast at a rate of $1 \mathrm{~mm} /$ year. The recent regional upheaval of Estonia is subject to the general postglacial uplift of Fennoscandia. According to Gregersen et al. (1991) the release of glacial loading stresses is not related to the present-day seismicity, partly because areas of northern Fennoscandia, where neotectonic faulting has taken place, are aseismic, and also because the uplift geometry is not reflected in the observed seismicity pattern and stress orientations.

The recent uplift irregularities in Estonia, as established by repeated levelling data, are frequently associated with older fault zones (Сильдвээ \& Мийдел, 1980). In other cases it appears that late dislocations have developed quite independently of older structures.

The distribution of the earthquakes in Estonia is not random. Their occurrence must be to a certain extent correlated with geology and tectonics. A considerable number of macroseismic events occur in the Paldiski-Pskov gravity and aeromagnetic anomaly zone, which is related to a deep-seated fault. Judging by the trend of the epicentre set, the foci at Lake Võrtsjärv may well be located in a minor cross fault.

The question now is what role, if any, these old faults play in the formation of cratonic structures. Let us look at Fig. 5, and ask whether the pattern of the cratonic structural features could be connected with the earthquake activity of the Paldiski-Pskov fault zone. The present data set (Fig. 5) does not allow us to rule this out. One rather comes to the opposite opinion, because the cratonic structure pattern seems to have no obvious correlation with the fault zone just mentioned.

Comparison of the structure contour with the bedrock relief patterns leads to the conclusion that direct morphostructures are infrequent in Estonia (Raukas et al., 1988).

The most prominent topographic elevation - Haanja Heights - in the eastern part of the Valmiera-Lokno uplift appertains to the struc- 


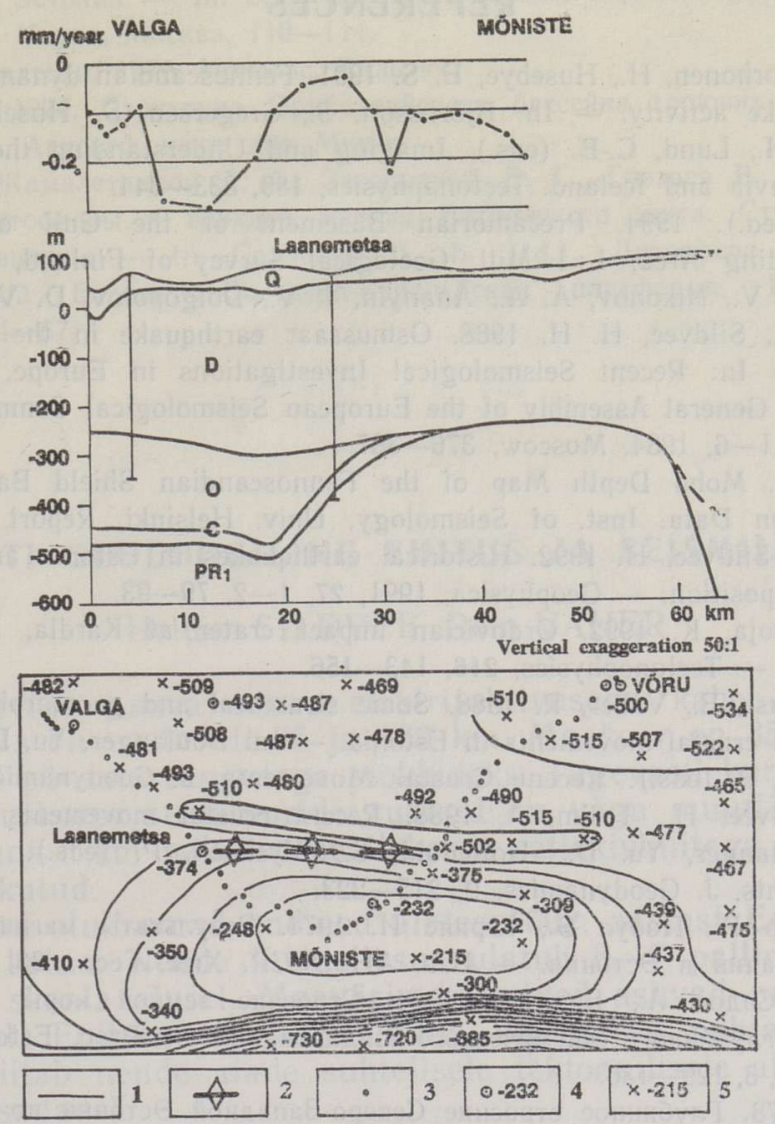

Fig. 7. Mõniste uplift, southeastern Estonia; map and section. Data from: Geological Survey of Estonia; Institute of Astrophysics and Atmospheric Physics, Estonian Academy of Sciences. 1 contour on top of the Precambrian basement; 2 axis of the recent uplift; 3 repeated levelling set-up; 4, 5 height of the basement in metres above mean sea-level: in borehole (4), at depth point of refraction survey (5). $\mathbf{P R}_{1}$ Paleoproterozoic

crystalline basement, E Cambrian, O Ordovician, D Devonian, Q Quaternary.

ture of this type. The recent uplift peak is found straight above the northern slope of the old anticline (Fig. 7). The instrumental epicentre locations as seen in Fig. 5 are in close agreement with the idea of an active structure.

With one exception, no expressions of the numerous linear structures in the bedrock relief were detected in northeastern Estonia. Macroseismic earthquakes in this region are unknown and instrumental epicentres are infrequent (Fig. 5). The problem of why some faults are active while others are aseismic has not yet been cleared up.

\section{ACKNOWLEDGEMENTS}

This work was supported by grants Nos. 317 and 319 of the Estonian Science Foundation and LCAOOO of the International Science Foundation. 


\section{REFERENCES}

Gregersen, S., Korhonen, H., Husebye, E. S. 1991. Fennoscandian dynamics: Present-day earthquake activity. - In: Björnsson, S., Gregersen, S., Husebye, E. S., Korhonen, H., Lund, C.-E. (eds.). Imaging and Understanding the Lithosphere of Scandinavia and Iceland. Tectonophysics, 189, 333-344.

Koistinen, T. (ed.). 1994. Precambrian Basement of the Gulf of Finland and Surrounding Area, 1:1 Mill. Geological Survey of Finland, Espoo.

Kondorskaya, N. V., Nikonov, A. A., Ananyin, I. V., Dolgopolov, D. V., Korhonen, H., Arhe, K., Sildvee, H. H. 1988. Osmussaar earthquake in the East Baltics of 1976. - In: Recent Seismological Investigations in Europe. Proceedings of the XIX General Assembly of the European Seismological Commission, Moscow, October 1-6, 1984. Moscow, 376-387.

Luosto, U. 1991. Moho Depth Map of the Fennoscandian Shield Based on Seismic Refraction Data. Inst. of Seismology, Univ. Helsinki, Report S-25, 43-50

Nikonov, A. A., Sildvee, H. 1992. Historical earthquakes in Estonia and their seismotectonic position. - Geophysica, 1991, 27, 1-2, 79-93.

Puura, V., Suuroja, K. 1992. Ordovician impact crater at Kärdla, Hiiumaa Island, Estonia. - Tectonophysics, 216, 143-156.

Raukas, A., Tavast, E., Vaher, R. 1988. Some structural and geomorphological aspects of recent crustal movements in Estonia. - In: Boulanger, Yu. D., Holtedahl, S., Vyskočil, P. (eds.). Recent Crustal Movements. J. Geodynamics, 10, 295-300.

Vallner, L., Sildvee, H., Torim, A. 1988. Recent crustal movements in Estonia. In: Boulanger, Yu. D., Holtedahl, S., Vyskočil, P. (eds.). Recent Crustal Movements. J. Geodynamics, 9, 215-223.

Андра Х., Вахер Р., Побул Э., Юрине И. 1974. Результаты магнитотеллурических исследований в Әстонии. - Изв. АН ЭССР. Хим. Геол., 23, 1, 50-53.

Анкудинов С., Садов А., Брио Х. 1994. Строение земной коры Прибалтики по данным глубинного сейсмического зондирования. - Proc. Estonian Acad. Sci. Geol., 43, 3, 129-136.

Булин Н. К. 1978. Глубинное строение Северо-Западной Эстонии по данным МОВЗ. - Сов. геология, 5, 123-129.

Булин Н. К., Афанасьева Н. А., Волков А. В., Проняева Е. А., Эрилис Е. Н. 1980. Афтершоки Эстонского землетрясения 1976 г. и глубинное строение эпицентральной зоны. - In: Сейсмичность и современные движения земной коры восточной части Балтийского щита. Апатиты, 24-39.

Вахер Р. М. 1983. Тектоника фосфоритно-сланцевого бассейна Северо-Восточной Әстонии. Автореф. канд. дис. Минск.

Вахер Р. М., Кууспалу Т. И., Пуура В. А., Эрисалу Э. К. 1964 . О геологическом положении сульфидных рудопроявлений в районе Ульясте. - In: Литология палеозойских отложений Эстонии. Таллинн, $33-53$.

Вахер Р. М., Мардла А. К. 1969. Опыт изучения тектонического строения участка Синимяэ (Северно-Восточная Эстония) методом электроразведки. - In: Вопросы региональной геологии Прибалтики и Белоруссии. Зинатне, Рига, $119-125$.

Пуура В. А. 1974. Структура южного склона Балтийского щита. Автореф. канд. дис. Таллинн.

Пуура В. А., Вахер Р. М., Клейн В. М., Коппельмаа Х. Я., Нийн М. И., Ванамб В. В., Кирс Ю. Э. 1983. Кристаллический фундамент Эстонии. Наука, Москва.

Пуура В. А., Кала Э. А. 1978. Плакантиклинали Северо-Восточной Эстонии. In: Локальные структуры Белоруссии и Прибалтики. Тезисы VII годичного совещания Комиссии по тектонике Белоруссии и Прибалтики. Вильнюс, $29-31$.

Пуура В., Мардла А. 1972. Структурное расчленение осадочного чехла в Эстонии. Изв. АН ЭССР. Хим. Геол., 21, 1, 72-78.

Сильдвээ Х. Х., Мийдел А. А. 1980. Опыт применения геолого-геофизических методов для интерпретации современных движений земной поверхности на тер- 
ритории Эстонии. - In: Современные движения земной коры. Теория, методы, прогноз. Наука, Москва, 110-114.

Тектоника Прибалтики. 1979. Мокслас, Вильнюс.

Туулинг И. И. 1990. Структура Прибалтийского бассейна горючих сланцев и фосфоритов. Автореф. канд. дис. Минск.

Шаров Н. В., Жамалетдинов А. А., Загородный В. Г., Глазнев В. Н. 1989. Структура литосферы и верхней мантии Балтийского щита. Структура раздела Мохоровичича. - In: Соллогуб В. Б. (еd.). Литосфера Центральной и Восточной Европы: Восточно-Европейская платформа. Наукова думка, Киев, 64-67.

\title{
EESTI GEOLOOGILINE EHITUS JA SEISMILISUS
}

\author{
Heldur SILDVEE, Rein VAHER
}

Maa vahevöös asuva suure elektrijuhtivusega kahe kihi keskmine sügavus Eestis on vastavalt 75 ja $160 \mathrm{~km}$. Maakoor on $35-50 \mathrm{~km}$ paks ning jaotatud süvamurrangutega plokkideks. Tugevasti kurrutatud kambriumieelse aluskorra struktuuride suunad on väga muutlikud. Aluskord on kaetud kuni $1 \mathrm{~km}$ paksuse pealiskorra settekivimitega, mille lasuvus on nõrgalt rikutud.

On esitatud olulisemad andmed alates 1602. aastast Eestis toimunud maavärinate kohta. Nende intensiivsus ulatub 6-7 pallini rahvusvahelise MSK-64 skaala alusel. Maavärinate kolded asuvad peamiselt 5-10 km sügavusel. Epitsentrite koondumine Võrtsjärve põhjaossa ja Eesti kagupiirile viitab nende alade suhtelisele tektoonilisele aktiivsusele viimastel aastasadadel.

\section{ГЕОЛОГИЧЕСКАЯ СТРУКТУРА И СЕЙСМИЧНОСТЬ ЭСТОНИИ}

\section{Хельдур СИЛЬДВЭЭ, Рейн ВАХЕР}

Средняя глубина двух проводящих слоев верхней мантии в Әстонии составляет соответственно 75 и 160 км. Мощность земной коры колеблется от 35 до 50 км. Земная кора разделена глубинными разломами на крупные блоки. Простирание структур сильно нарушенного докембрийского складчатого фундамента очень изменчиво. Фундамент покрыт слабо нарушенным осадочным чехлом мощностью менее 1 км.

В статье приведены основные параметры землетрясений Эстонии начиная с 1602 г. Их интенсивность по шкале МСК-64 достигает 6-7 баллов. Глубина очагов большинства землетрясений колеблется в пределах 5-10 км. Концентрация эпицентров землетрясений в северной части оз. Выртсъярв и на юго-восточной границе Эстонии в пределах Вальмиеро-Локновского поднятия указывает на современную тектоническую активность этих районов. 